\title{
Physical Activity Reduces Anxiety And Regulates Brain Fatty Acid Synthesis
}

\section{CURRENT STATUS: ACCEPTED}

- Molecular Brain DBMC

Arkadiusz Damian Liśkiewicz

Akademia Wychowania Fizycznego imienia Jerzego Kukuczki w Katowicach

Marta Przybyła

Akademia Wychowania Fizycznego imienia Jerzego Kukuczki w Katowicach

Anna Wojakowska

Polska Akademia Nauk

Łukasz Marczak

Polska Akademia Nauk

Katarzyna Bogus

Slaski Uniwersytet Medyczny w Katowicach

Marta Nowacka-Chmielewska

Akademia Wychowania Fizycznego imienia Jerzego Kukuczki w Katowicach

Daniela Liśkiewicz

Akademia Wychowania Fizycznego imienia Jerzego Kukuczki w Katowicach

Andrzej Małecki

Akademia Wychowania Fizycznego imienia Jerzego Kukuczki w Katowicach

Jarosław Barski

Slaski Uniwersytet Medyczny w Katowicach

Joanna Lewin-Kowalik

Slaski Uniwersytet Medyczny w Katowicach

Michal Toborek

University of Miami School of Medicine

mtoborek@med.miami.eduCorresponding Author

ORCiD: https://orcid.org/0000-0003-4475-2119 
DOI:

$10.21203 / \mathrm{rs} .2 .21960 / \mathrm{v} 1$

\section{KEYWORDS}

Physical activity, neurobehavior, metabolome, neurogenesis 


\section{Abstract}

Physical activity impacts brain functions, but the direct mechanisms of this effect are not fully recognized or understood. Among multidimensional changes induced by physical activity, brain fatty acids (FA) appear to play an important role; however, the knowledge in this area is particularly scarce. Here we performed global metabolomics profiling of the hippocampus and the frontal cortex (FC) in a model of voluntary running in mice. Examined brain structures responded differentially to physical activity. Specifically, the markers of the tricarboxylic acid (TCA) cycle were downregulated in the FC, whereas glycolysis was enhanced in the hippocampus. Physical activity stimulated production of myristic, palmitic and stearic FA; i.e., the primary end products of de novo lipogenesis in the brain, which was accompanied by increased expression of hippocampal fatty acid synthase (FAS), suggesting stimulation of lipid synthesis. The changes in the brain fatty acid profile were associated with reduced anxiety level in the running mice. Overall, the study examines exercise-related metabolic changes in the brain and links them to behavioral outcomes.

\section{Full-text}

Due to technical limitations, full-text HTML conversion of this manuscript could not be completed. However, the manuscript can be downloaded and accessed as a PDF. 